\title{
Acetyl-CoA Carboxylase Alpha Gene Polymorphism and Its Association with Milk Fatty Acid of Holstein Friesian Using Real-Time PCR Method
}

\author{
R. Azis ${ }^{\mathrm{a}, *}$, Jakaria ${ }^{\mathrm{b}}$, A. Anggraenic ${ }^{\mathrm{c}}$ \& A. Gunawan ${ }^{\mathrm{b}}$ \\ ${ }^{a}$ Animal Science Program, Faculty of Science, University of Nahdlatul Ulama Blitar, \\ Jalan Masjid No.22 Kota Blitar, Blitar 66117, Indonesia \\ bDepartment of Animal Production and Technology, Faculty of Animal Science, IPB University \\ (Bogor Agricultural University) \\ Jalan Agatis, Kampus IPB Dramaga, Bogor 16680, Indonesia \\ 'Indonesian Research Institute for Animal Production (IRIAP), Bogor \\ Jalan Veteran III, Bogor 16720, Indonesia \\ *Corresponding author: rosialfatih1953@gmail.com \\ (Received 17-03-2020; Revised 10-06-2020; Accepted 18-06-2020)
}

\begin{abstract}
Milk fatty acids are largely affected by genetic factors. Acetyl-CoA Carboxylase Alpha (ACACA) gene is one of the important genes in regulation and metabolic function of milk fatty acids in dairy cattle. The objective of this study was to find out the relationship of single nucleotide polymorphism (SNP) ACACA gene with milk fatty acid trait in local dairy cattle. A total of 277 samples of Holstein Friesian (HF) were collected from Indonesian Research Institute for Animal Production (IRIAP), Animal Breeding Center and Forage Feed of Baturraden (ABCFFB), Central Java Province, Animal Husbandry Training Center of Cikole (AHTCC), West Java Province, Singosari Artificial Insemination Station (Singosari AIS), East Java Province, and Lembang Artificial Insemination (Lembang AIS), West Java Province, Indonesia. Genotyping of this SNP marker (g.2203G $>$ T) was analyzed using the realtime Polymerase Chain Reaction (PCR) based on the hybridization TaqMan probe as the method for allelic discrimination. Milk samples were analyzed using Gas Chromatography and Mass Spectrometry (GCMS). The results of this study revealed the GG and GT genotypes. The proportion of the GG genotype frequency (0.88) was higher than the GT genotype $(0.11)$ and the G Allele frequency was shown higher than the $T$ allele in all locations, i.e., 0.942 and 0.08 , respectively. The ACACA gene g.2203G $>T$ SNP was significant $(\mathrm{p}<0.05)$ for lauric $(\mathrm{C} 12: 0)$ and dodecanoic $(\mathrm{C} 17: 1)$ acids. It was concluded that the ACACA gene g.2203G>T SNP could be useful as a marker selection for milk fatty acid such as lauric and dodecanoic fatty acids.
\end{abstract}

Keywords: real-time PCR; TaqMan MGB probe; genotype; ACACA gene; Holstein Friesian

\section{INTRODUCTION}

Milk fat is a component of milk which has a high economic value. Milk fat can be a determinant of the sustainability of dairy cattle business in this country. Milk with fat quality is increasingly required for cheese products and other functional foods. Milk produced by HF dairy cattle contains high fat and total milk fat consisted of $65.67 \%$ of total saturated fatty acids (SFA), $29.56 \%$ of total monounsaturated fatty acid (MUFA), and $4.78 \%$ of total polyunsaturated fatty acid (PUFA) (Pilarczyk et al., 2015). Previous studies reported that consuming foods containing high SFA and trans-fat associated with cardiovascular disease, coronary heart disease, diabetes, and stroke (Livingstone et al., 2012; Micha \& Mozaffarian, 2010; Salter, 2013; Siri-Tarino et al., 2010), and consuming MUFA and PUFA were correlated with improving human health (Livingstone et al., 2012; Siri-Tarino et al., 2010). MUFA and PUFA are currently used to reduce the number and size of tumor disease (Torkildsen et al., 2012).
Milk fatty acid is a quantitative trait which is controlled by multi genes in biological pathways of milk fatty acid synthesis (Abbas \& Sibirny, 2011; Marchitelli et al., 2013; Wang et al., 2015). Gene candidate studies have shown that several genes have significant roles in de-novo milk fatty acid synthesis. The genes involved in controlling fatty acids synthesis are Diacylglycerol Acyltransferase-1 (DGAT1), Stearoyl-CoA Desaturase-1 (SCD1), and Acetyl-CoA Carboxylase Alpha (ACACA) genes (García-Fernández et al., 2010; Gunawan et al., 2019; Matsumoto et al., 2012; Shin et al., 2011). However, the ACACA enzyme is found evenly in many tissues and the highest level is found in the lipogenic tissue of the mammary gland during breastfeeding, apart from the liver and adipose tissues (Matsumoto et al., 2012; Singh et al., 2015). The Acetyl-CoA Carboxylase Alpha gene has a key role in milk fatty acid metabolism which controls Acetyl-CoA Carboxylase in the regulation of fatty acid synthesis (Gacek et al., 2017; Matsumoto et al., 2012). The activity of Acetyl-CoA Carboxylase in the cell increased to lead the increasing production of Malonyl- 
CoA, as a substrate for palmitic acid and long-chain fatty acid synthesis (Abu-Elheiga et al., 2012; Najafpanah et al., 2014). The Acetyl-CoA Carboxylase enzyme is expressed in all the lipogenic tissues such as adipose tissue, liver, and mammary gland during lactation (RopkaMolik et al., 2017; Wang et al., 2015). Based on the previous studies, the ACACA gene in 5'UTR (untranslated region) had a significant effect on milk fatty acid composition in beef cattle (Zhang et al., 2010). The Acetyl-CoA Carboxylase Alpha gene is a very strong gene for fatty acid which is located on chromosome 19 (19q13- p14), with the length of $6203 \mathrm{bp}$ consisting of 56 exons and 55 introns (Shin et al., 2011). The Acetyl-CoA Carboxylase Alpha gene is one of the very important genes involved in milk fatty acid synthesis and the limiting level of this enzyme will affect the biosynthesis of palmitic acid and long-chain fatty acid. However, the effect of this gene on milk fatty acid has not been evaluated in local dairy cattle.

A technology which works rapidly in evaluating gene is a real-time Polymerase Chain Reaction (realtime PCR). Real-time PCR is a technology in molecular biology for Single Nucleotide Polymorphism (SNP) identification rapidly in resulting genotype data (Kozera \& Rapacz, 2013). Real-time PCR utilizes TaqMan MGB probe fluorescence which has been widely used in other fields of molecular biology including in the livestock (Bora et al., 2011; Hymas et al., 2010; Lanfranco et al., 2009; Navarro et al., 2015). The advantage of real-time PCR in gene genotyping requires only a few samples, monitoring directly PCR products without electrophoresis, with high sensitivity and high accuracy of genotype data (Wei et al., 2013). Therefore, the TaqMan MGB probe in real-time PCR could be used in identifying the ACACA gene in local dairy cattle. This study aimed to identify the ACACA gene using TaqMan real-time PCR and its effect on milk fatty acid traits in dairy cattle.

\section{MATERIALS AND METHODS}

\section{Blood and Milk Samples}

Blood samples were collected from female Holstein Friesian (HF) dairy cattle from Indonesian Research Institute for Animal Production (IRIAP), Bogor, West Java (113 heads), Animal Husbandry Training Center of Cikole (AHTCC), Bandung, West Java (42 heads), Animal Breeding Center and Forage Feed of Baturraden (ABCFFB), Banyumas, Central Java (76 heads); as well as from male HF cattle from Singosari Artificial Insemination Station (Singosari AIS), Malang, East Java (29 heads), and Lembang Artificial Insemination (Lembang AIS), Bandung, West Java (17 heads),
Indonesia. Genomic DNA was extracted from each animal using Genomic DNA Purification Mini Kit (Thermo Scientific) in the Laboratory of Animal Molecular Genetic, Faculty of Animal Science, IPB University and Research Institute of Animal Production, Ciawi, Bogor, Indonesia.

Milk samples were collected from HF cows within 2-8 months of lactation and 1-4 periods of lactation from ABCFFB. All of these cows were fed under the tightly controlled conditions of the same feeding program. Milk samples were analyzed using Gas Chromatography and Mass Spectrometry (GCMS) at the Technical Implementation Unit of Integrated Laboratory, Diponegoro University, Semarang. As much as $0.5 \mu \mathrm{L}$ of esterified milk fat samples were injected into the GC column by auto sampling. The separation was performed in the RTx1-MS column of Restech 30 $\mathrm{m} \times 0.5 \mathrm{~mm}$ ID $0.25 \mu \mathrm{m}$, with the stationary phase of Polydimethyl Ciloxan, injector temperature of $280^{\circ} \mathrm{C}$, column temperature of $70^{\circ} \mathrm{C}$ raised to $300^{\circ} \mathrm{C}$ with an increase of $10^{\circ} \mathrm{C} / \mathrm{min}$, the eluent used was helium gas with a flow rate of $1.15 \mathrm{~mL} / \mathrm{min}$. The MS detector used was Electron Multifier Detector (EMD) $70 \mathrm{MeV}$. The results of the analysis in the form of a mass spectrum displayed on the post-run GCMS software and compared with the library wiley9.lib.

\section{Designing of Primer and TaqMan Probe}

Primer and probe of the ACACA gene were designed using Primer Express program Primer 3.0.1 (Perkin-Elmer, Applied Biosystems) based on the ACACA gene sequence with No. Access Genbank: AJ276223 at the mutation site g.2203G $>$ T (Figure 1). The sequence of forward primer was 5'-GCC TCC CTG CCT TCA GAT AAA-3' and reverse primer was 5'-GGG AAG TCC CCA GTA TCA TTT TT-3'. The sequence of probe 1 was 5'-(FAM) TGA AGT GTA TAG GAC TTA GAA-3' and probe 2 was 5'- (VIC) TAT AGG ACT TAT AAA GGG C-3'. TaqMan probe on the SNP was bold where Probe 1 was synthesized by FAM ${ }^{\mathrm{TM}}$ dye-labeled TaqMan ${ }^{\circledR}$ MGB probe with blue dye for identifying specific T allele at 5' end reporter whereas probe 2 was synthesized by VIC ${ }^{\mathrm{TM}}$ dye-labeled TaqMan ${ }^{\circledR}$ MGB probe with blue-pink dye to identify specific $G$ allele at $3^{\prime}$ end quencher as describe at Figure 1.

\section{Genotyping of ACACA Gene}

Amplification of the ACACA gene was conducted by using the real-time PCR with thermal cycler consisting of denaturation at $95^{\circ} \mathrm{C}$ for $20 \mathrm{~s}$, annealing temperature at $60^{\circ} \mathrm{C}$ for $60 \mathrm{~s}$, and extension at $95^{\circ} \mathrm{C}$ for $3 \mathrm{~s}$,

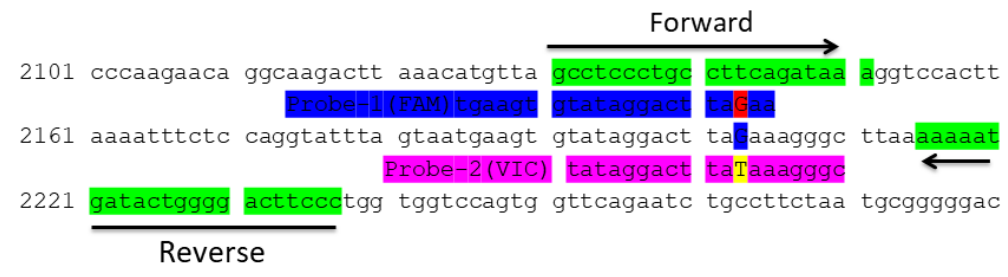

Figure 1. Primer and probe (forward-reverse) ACACA gene 
respectively, each for 40 cycles. PCR reaction was made with $1 \mu \mathrm{L}$ DNA template, $5 \mu \mathrm{L}$ TaqMan ${ }^{\circledR}$ GTXpressTM Master Mix containing the buffer, Uracil-N-glycosylase, deoxyribonucleotides, uridine, passive reference dye (ROX), TaqGold DNA polymerase (Applied Biosystems, Foster City, CA USA), 0.5 uL primer, and Taqman-MGB probe (forward and reverse), and $3.5 \mu \mathrm{L}$ real-time PCR grade water. This reaction was distributed $10 \mu \mathrm{L}$ in MicroAmp Optical 96-Well reaction plates with the ratio of DNA template and reaction 1:9 ( $\mathrm{vol} / \mathrm{vol})$, and using non-template DNA as a control. MicroAmp Optical 96Well reaction plates were covered by sealing-foil 96-well and centrifuged with $2500 \mathrm{rpm}$ for 3 minutes.

Genotyping of the ACACA gene g.2203G $>$ T SNP on each sample would be read by curve fluorescence which was received in real-time PCR machine. Genotype data of all samples would be formed by a cluster genotype based on fluorescence. Homozygous GG genotype was characterized by FAM fluorescent, heterozygous GT genotype was characterized by VIC and FAM fluorescent, and homozygous TT genotype was demonstrated by VIC fluorescent. All of the data were recorded by 7500 ver.2.0.6 software (Applied Biosystems, Foster City, CA, USA) and the output of the data was obtained in the form of Microsoft Excel.

\section{Data Analysis}

Genotype data of the ACACA gene g.2203G>T SNP of the HF cattle observed were analyzed using genotype frequency and allele frequency by popgen 32 software ver. 1:31. The PROC General Linear Models (GLM) procedure of SAS ver. 9.2 was used to find the association between ACACA gene polymorphism and individual milk fatty acid. The mathematical model analysis was as follows:

$$
\mathrm{Y}_{\mathrm{ijk} k \mathrm{mn}}=\mu+\mathrm{G}_{\mathrm{i}}+\mathrm{L}_{\mathrm{j}}+\mathrm{P}_{\mathrm{k}}+\mathrm{S}_{1}+\mathrm{T}_{\mathrm{m}}+\varepsilon_{\mathrm{n}}
$$

where $Y_{\mathrm{ijklmn}}$ was individual component of milk fatty acid traits, $\mu$ was overall means for each trait (24 fatty acids), $G_{i}$ was the $i^{\text {th }}$ genotype effect $(G G, G T), L_{j}$ was the $j^{\text {th }}$ month of lactation effect $(2-4,5-8), P_{k}$ was the $\mathrm{k}^{\text {th }}$ period of lactation effect $(1,2,3-4), \mathrm{S}_{1}$ the $1^{\text {th }}$ season of calving effect $(1-6,7-12), \mathrm{T}_{\mathrm{m}}$ was the the $\mathrm{m}^{\text {th }}$ year of calving effect 2011, 2012), and $\varepsilon_{n}$ was the $n^{\text {th }}$ random residual effect.

\section{RESULTS}

\section{Amplification of ACACA Gene}

The ACACA gene was successfully amplified using primers and probes. The ACACA gene amplification was carried out under the condition of Thermal Cycler real-time PCR, namely at denaturation temperature of $95^{\circ} \mathrm{C}$ for 20 seconds, annealing temperature of $60^{\circ} \mathrm{C}$ for 1 minute, and extension temperature of $95^{\circ} \mathrm{C}$ for 3 seconds which was run for 40 cycles. The results of the ACACA gene using TaqMan MGB Probe in Holstein Friesian cattle only found two genotypes, i.e., GG and GT. The results of real-time PCR products were displayed in Figure 2 and 3. Genotyping of the ACACA gene was shown in the allelic discrimination plot, whereas GG genotypes were shown by clustering data with blue dye and GT genotypes were shown by clustering data with green dye, as shown in Figure 4.

\section{Polymorphism of ACACA Gene}

The results of genotype and allele frequencies of the ACACA gene g.2203G>T SNP are presented in Table 1. The average frequency of GG genotype was 0.885 and GT Genotype was 0.115. The frequencies of G and $\mathrm{T}$ alleles were 0.942 and 0.058 , respectively. Generally, the allele frequency of the ACACA gene in dairy cattle showed that $G$ allele was predominant compared to $\mathrm{T}$ allele and the frequency of GG genotype was higher than the frequency of GT genotype in dairy cattle.

\section{The Association of ACACA Gene with Milk Fatty Acid}

The result of the association analysis showed that the genotype of the ACACA gene g.2203G>T SNP did not significantly affect milk fatty acid of dairy cattle. However, some association results showed that GG genotype had higher SFA (lauric acid) than GT genotype $(\mathrm{p}<0.05)$ and GT genotype had higher UFA (dodecanoic

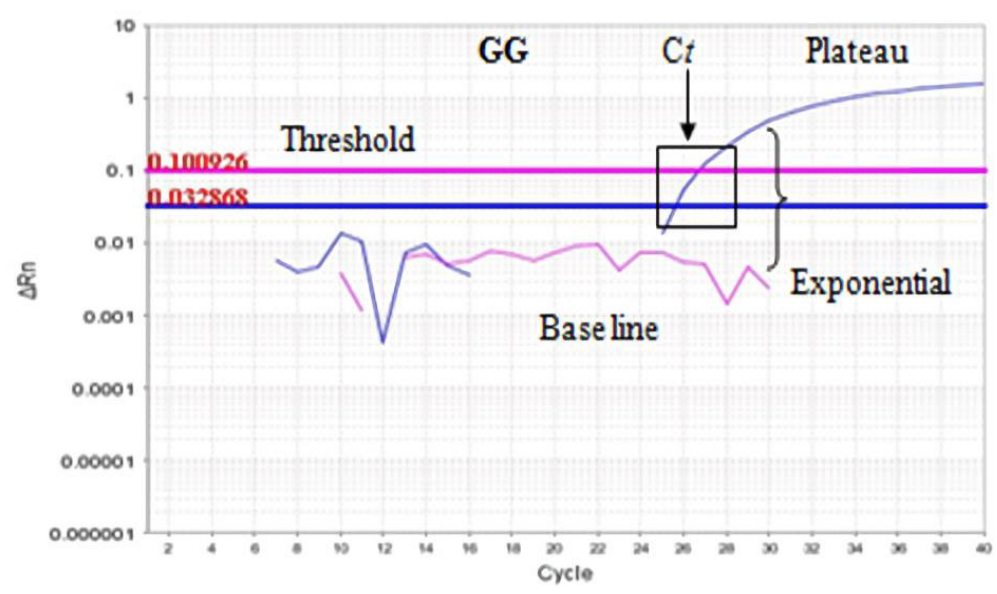

Figure 2. Amplification plot of GG genotype of ACACA gene in dairy cattle, a = AHGJ8BB-T, $\square=$ AHGJ8BB-G 


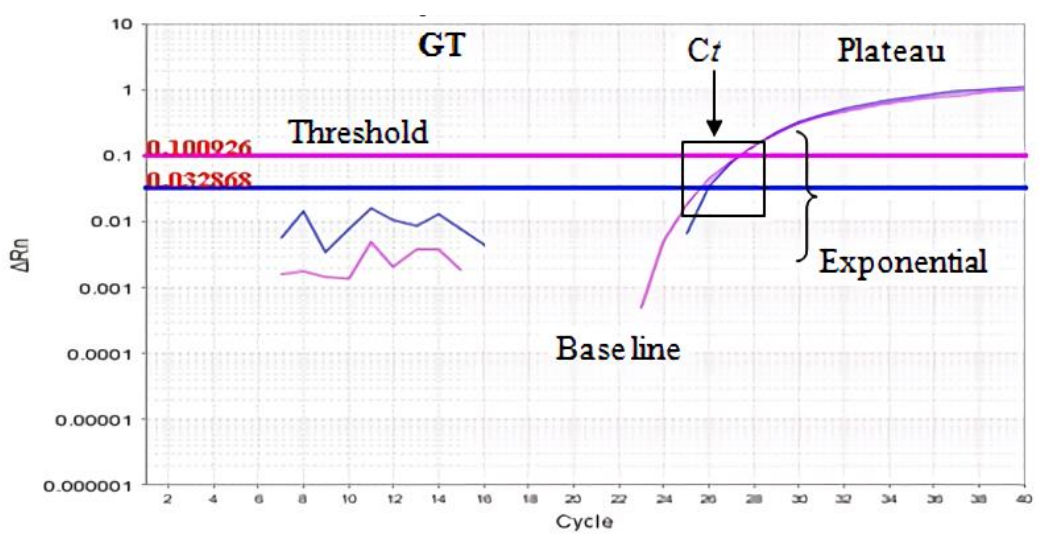

Figure 3. Amplification plot of GT genotype of ACACA gene in dairy cattle, $\square=$ AHGJ8BB $-\mathrm{T}, \square=$ AHGJ8BB-G

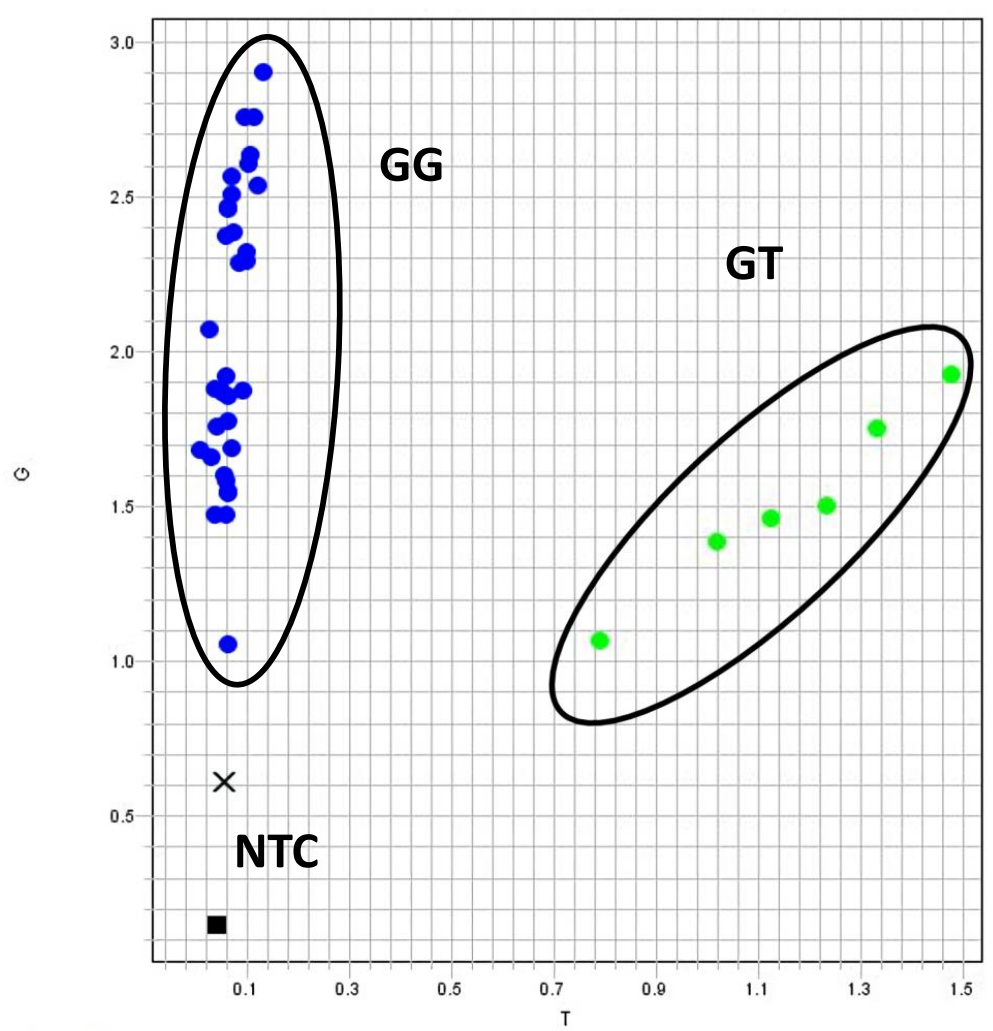

Figure 4. Allelic discrimination plot GG, GT genotype, and NTC of ACACA gene in dairy cattle, $=\mathrm{T} / \mathrm{G}, \mathbf{O}=\mathrm{G} / \mathrm{G}, \mathrm{x}=$ Undetermined.

acid) than GG genotype $(\mathrm{p}<0.05)$. The results of the association analysis are presented in Table 2.

\section{DISCUSSION}

The ACACA gene has a key role in the biological system to synthesize milk fatty acid. The ACACA enzyme is found almost in the entire tissue, but the highest level was found in the lipogenic tissue of the mammary gland during lactation (Marchitelli et al., 2013; Matsumoto et al., 2012). Based on previous research, the ACACA gene was a potential candidate gene in fatty acid. The ACACA gene can be used as a SNP marker for the composition of fatty acids in meats of beef, pork, and goat's milk (Abu-Elheiga et al., 2012; Najafpanah et al., 2014; Zhang et al., 2010).

The exploration of ACACA gene polymorphisms in this study uses a real-time PCR technology. Realtime PCR is in principle the same as conventional PCR (Kozera \& Rapacz, 2013). The advantages of real-time PCR are the amplification products can be monitored in real-time without electrophoresis (Divis et al., 2010). Real-time PCR technology utilizes a fluorescent TaqMan MGB probe, where the TaqMan MGB Probe is designed to stick to the accumulation of products that bind the target sequence (Wei et al., 2013). The utilization of TaqMan MGB probes in real-time PCR as a detection system has been widely used in genotyping and gene 
Table 1. Allele and genotype frequency of ACACA gene in dairy cattle

\begin{tabular}{|c|c|c|c|c|c|}
\hline \multirow{2}{*}{ Location } & \multirow{2}{*}{$\mathrm{n}$} & \multicolumn{2}{|c|}{ Genotype frequency } & \multicolumn{2}{|c|}{ Allele frequency } \\
\hline & & GG & GT & G & $\mathrm{T}$ \\
\hline IRIAP & 113 & 0.973 & 0.027 & 0.987 & 0.013 \\
\hline ABCFFB & 76 & 0.895 & 0.105 & 0.947 & 0.053 \\
\hline AHTCC & 42 & 0.905 & 0.095 & 0.952 & 0.048 \\
\hline Singosari AIS & 29 & 0.828 & 0.172 & 0.914 & 0.086 \\
\hline Lembang AIS & 17 & 0.824 & 0.176 & 0.912 & 0.088 \\
\hline Total & 277 & 0.885 & 0.115 & 0.942 & 0.058 \\
\hline
\end{tabular}

Note: IRIAP= Indonesian Research Institute for Animal Production, Bogor, West Java; ABCFFB= Animal Breeding Center and Forage Feed of Baturraden, Banyumas, Central Java; AHTCC $=$ Animal Husbandry Training Center of Cikole, Bandung, West Java; Singosari AIS= Singosari Artificial Insemination Station, Malang, East Java; Lembang AIS= Lembang Artificial Insemination Station, Bandung, West Java, Indonesia.

Table 2. The association of ACACA gene polymorphism with milk fatty acid

\begin{tabular}{|c|c|c|c|c|}
\hline \multirow{2}{*}{ Milk fatty acid } & \multicolumn{2}{|c|}{ Genotypes } & \multirow{2}{*}{ Probability } & \multirow{2}{*}{ Sig } \\
\hline & GG $(n=36)$ & GT $(n=7)$ & & \\
\hline \multicolumn{5}{|l|}{ Saturated fatty acid (SFA) } \\
\hline \multicolumn{5}{|l|}{ a. Short chain (C3-C9) } \\
\hline Propionic (C3:0) & $1.14 \pm 0.20$ & $0.82 \pm 0.41$ & 0.4864 & Ns \\
\hline Butyric (C4:0) & $0.45 \pm 0.06$ & $0.59 \pm 0.12$ & 0.3131 & Ns \\
\hline Caproic (C6:0) & $1.61 \pm 0.08$ & $1.51 \pm 0.15$ & 0.5690 & Ns \\
\hline Caprylic (C8:0) & $2.29 \pm 0.17$ & $2.14 \pm 0.35$ & 0.6963 & Ns \\
\hline Nonanoic (C9:0) & $0.18 \pm 0.06$ & $0.44 \pm 0.12$ & 0.0683 & Ns \\
\hline Sub Total & 5.67 & 5.50 & & \\
\hline \multicolumn{5}{|l|}{ b. Medium chain (C10-C14) } \\
\hline Capric (C10:0) & $1.65 \pm 0.07$ & $1.53 \pm 0.37$ & 0.4713 & Ns \\
\hline Lauric (C12:0) & $5.99 \pm 0.09^{a}$ & $5.55 \pm 0.18^{b}$ & 0.0459 & \\
\hline Tridecanoic (C13:0) & $0.42 \pm 0.04$ & $0.35 \pm 0.07$ & 0.3806 & Ns \\
\hline Myristic (C14:0) & $24.75 \pm 0.28$ & $25.24 \pm 0.56$ & 0.4335 & Ns \\
\hline Sub Total & 32.81 & 32.67 & & \\
\hline \multicolumn{5}{|l|}{ c. Long chain (C14-C22) } \\
\hline Pentadecanoic (C15:0) & $4.68 \pm 0.08$ & $4.82 \pm 0.16$ & 0.4411 & Ns \\
\hline Palmitic (C16:0) & $32.87 \pm 0.29$ & $32.78 \pm 0.59$ & 0.9276 & Ns \\
\hline Stearic (C18:0) & $1.11 \pm 0.06$ & $1.06 \pm 0.12$ & 0.7456 & Ns \\
\hline Arachidic (C20:0) & $1.61 \pm 0.05$ & $1.61 \pm 0.10$ & 0.9993 & Ns \\
\hline Behenic (C22:0) & $1.03 \pm 0.04$ & $0.96 \pm 0.08$ & 0.4996 & Ns \\
\hline Sub total & 41.30 & 41.26 & & \\
\hline Total SFA & 79.78 & 79.43 & & \\
\hline \multicolumn{5}{|l|}{ Unsaturated fatty acid (UFA) } \\
\hline \multicolumn{5}{|l|}{ a. MUFA (C14:1) - (C22:1) } \\
\hline Caproleic (C10:1) & $0.16 \pm 0.0$ & $0.13 \pm 0.02$ & 0.2717 & Ns \\
\hline Myristoleic (C14:1) & $3.44 \pm 0.04$ & $3.53 \pm 0.80$ & 0.3492 & Ns \\
\hline Hexadecenoic (C16:1) & $7.54 \pm 0.27$ & $7.83 \pm 0.55$ & 0.6418 & Ns \\
\hline Heptadecanoic (C17:1) & $1.67 \pm 0.07$ & $1.56 \pm 0.14$ & 0.4869 & Ns \\
\hline Eicosanoic (C20:1) & $2.95 \pm 0.07$ & $3.23 \pm 0.15$ & 0.0910 & Ns \\
\hline Dodecanoic (C12:1 n-3) & $0.14 \pm 0.06^{\mathrm{a}}$ & $0.29 \pm 0.06^{b}$ & 0.0399 & \\
\hline Erucic (C22:1) & $0.41 \pm 0.04$ & $0.42 \pm 0.07$ & 0.9591 & Ns \\
\hline Sub Total & 16.31 & 16.99 & & \\
\hline \multicolumn{5}{|l|}{ b. PUFA (C4:2) - (C22:4) } \\
\hline Butanedioic (C4:4) & $1.13 \pm 0.09$ & $0.77 \pm 0.17$ & 0.0736 & Ns \\
\hline Linoleic (C18:2 n-6) & $1.28 \pm 0.05$ & $1.21 \pm 0.09$ & 0.5290 & Ns \\
\hline Arachidonic (C20:4 n-3) & $1.16 \pm 0.02$ & $1.14 \pm 0.03$ & 0.6268 & Ns \\
\hline Sub total & 3.57 & 3.12 & & \\
\hline Total UFA & 19.88 & 20.11 & & \\
\hline
\end{tabular}

Note: Means in the same row with different superscripts differ significantly $(\mathrm{p}<0.05)$; ns= non-significant. 
quantification. The probe molecule has two parts in detecting genes, namely the dye reporter at the $5^{\prime}$ end and the quencher at the 3' end (Bora et al., 2011; Navarro et al., 2015). The dye probe reporter functions as a fluorophore donor at the $5^{\prime}$ end, while the dye probe quencher functions as a fluorophore receiver at the $3^{\prime}$ end. Both probes hybridize only with the target sequence in the annealing phase (Bora et al., 2011; Navarro et al., 2015). Hybridization of wild-type probes only hybridizes with wild-type targets, whereas mutant probes hybridize with mutant targets (Demeke et al., 2010; Divis et al., 2010). The result of the hybridization is the production of fluorescence signals. If the probe molecule does not hybridize with the target sequence, it will not produce a fluorescence signal. Fluorescence curves of the probe hybridization results can be monitored in real-time (Demeke et al., 2010; Divis et al., 2010).

The ACACA gene was amplified in the $22^{\text {nd }}$ and $26^{\text {th }}$ cycles and the fluorescence curve passed the Cycle threshold $(\mathrm{Ct})$ line from the base-line (initial amplification) to the exponential phase and towards plateau (extension) phase (Figure 2 and 3). The $\mathrm{Ct}$ values of the two (VIC and FAM) fluorescence curves were 0.100926 and 0.032868 , respectively. The fluorescence curve that had passed through the $\mathrm{Ct}$ indicated that the process was successfully in amplification phase. The success of the fluorescence curve passed the $\mathrm{Ct}$ value was used as an indicator of the success of amplification of the target gene and was used as a basis for determining the genotype of an individual sample accurately (Bora et al., 2011; Demeke et al., 2010; Divis et al., 2010). The Ct values were related to DNA quality of samples (Kozera \& Rapacz, 2013). The Ct value was determined automatically when the curve was in the exponential phase (Divis et al., 2010).

The result of the amplification of the ACACA gene g.2203G>T SNP was successfully analyzed using TaqMan Probe real-time PCR. There was a mutation $G$ toT SNP at base 2203 (GeneBank accesion number AJ_276223). The ACACA gene genotype in individual dairy cattle was shown by the amplifying curve. The GG genotype was shown by the FAM fluorescence with blue dye, whereas the GT genotype was shown by the FAM and VIC fluorescence with blue and pink dyes. All of the samples ACACA gene g.2203G>T SNP could be shown by clustering genotype where GG genotype was shown by clustering FAM fluorescence with blue dye, GT genotype was shown by clustering FAM and VIC fluorescence with green dye and non-template control (NTC) with black dye (Figure 4). The TT genotype in this study was not found. It shows that the same result reported by Zhang et al. (2010) that GG and GT genotypes were found in Brangus and Romosinuano cattle.

The result of the ACACA gene genotype was shown in Table 1. Generally, the frequency of GG genotype (0.885) was greater in all locations of dairy cattle than the frequency of GT genotype (0.115). The results of this study did not find the TT genotype. This result could be influenced by the source of bulls of Artificial Insemination Station (Singosari AIS and Lembang AIS) used. Both of AIS sources did not inherit the TT genotype. It is likely that the bulls used in the GG genotype were mated with GT genotype or GT genotype were mated with GG genotype. The mating system with the genotype was one of the reasons for the absence of the TT genotype in all population.

The results of allele frequency showed that the average frequency of $G$ allele were higher (0.942) than the frequency of $\mathrm{T}$ allele (0.058). The high frequency of $\mathrm{G}$ allele would be an indication that the majority of individual dairy cattle did not have mutation on this SNP (2203 $\mathrm{bp}$ ). This condition was provable by the high frequency of the $G$ allele as a wild type and the low frequency of $\mathrm{T}$ allele as mutant type. The mutation would cause the changes in the level of substitution, deletion, insertion, and insertion in the DNA (Nei, 1987). However, the ACACA gene in this study was polymorphic. This ACACA gene showed more than one allele type in all locations. Based on the result reported by Gunawan et al. (2018) the frequency of polymorphic allele was less than 0.99 (>0.01). Polymorphisms of ACACA gene have been reported in some species, among those were cattle (Shin et al., 2011), goat (Najafpanah et al., 2014), mice (Abu-Elheiga et al., 2012), duroc (Braglia et al., 2014), and human (Abu-Elheiga et al., 1995).

The results of milk fatty acid are presented in Table 2. The milk fatty acid composition was identified as SFA, MUFA, and PUFA which consist of 21 types of fatty acid. SFA was consist of 5 types of short-chain fatty acid (propionic, butyric, caproic, caprylic, and nonanoic), 4 types of medium-chain fatty acid (capric, lauric, tridecanoic, and mirystic), and 6 types of long-chain fatty acids (pentadecanoic, palmitic, heptadecanoic, stearic, arachidic, and behenic). MUFA was identified with 7 types of fatty acid (caproleic, myristoleic, hexadecenoic, heptadecanoic, eicosanoic, dodecanoic, and erucic). PUFA was identified 3 kinds of fatty acid (butanedioic, linoleic, and arachidonic). The total composition of SFA, MUFA, and PUFA were 79.43\%-79.78\%, 16.31\%-16.99\%, and $3.12 \%-3.57 \%$, respectively.

The effect of ACACA gene polymorphism was not significant ( $p>0.05$ ) on milk fatty acid (SFA, MUFA, and PUFA) except on lauric acid (C12:0) and dodecanoic acid (C12:1 n-3). ACACA polymorphism which has a potentially significant effect were on nonanoic acid, eicosanoic acid, and butanedioic acid. GG genotype has lauric acid content that was greater $(5.99 \pm 0.09)$ than GT genotype $(5.55 \pm 0.18)$. On the contrary, in the dodecanoic content, GT genotype was higher than GG genotype. Therefore, on the other side, SFA content that generally GG genotype was higher than the GT genotype. However, it was in contrast with MUFA, especially dodecanoic (C12: $1 \mathrm{n}-3)$ acid that the GT genotype had a higher content than the GG genotype. The result of the study by Zhang et al. (2010) showed that the GG genotype had a more powerful effect than the GT genotype on total SFA, and the opposite were found in MUFA and PUFA.

The result of fatty acid content is influenced by gene activity which controls the formation of fatty acids in milk (Abbas \& Sibirny, 2011; Gacek et al., 2017; Wang et al., 2015). Livestock, especially cattle could not synthesize linoleic fatty acid (C18: 2) and linolenic fatty acid (C18: $3 \mathrm{n} 3)$, and the other types of PUFA fatty acids. PUFA fatty acids produced by the feed consumed 
(Ropka-Molik et al., 2017). SFA biosynthesis by fatty acid synthesis (FAS) then experienced extension or microsomal desaturation in the adipose tissue to produce MUFA such as myristoleic acid (C14:1), hexadecanoic acid (C16:1), and vaccenic acid (C18:1) (Livingstone et al., 2012; Ropka-Molik et al., 2017; Zhang et al., 2010).

The SFA content in this study was the highest (myristic, pentadecanoic, and palmitic), followed by MUFA (myristoleic) and PUFA (linoleic) (Table 2). The similar results found in this research were reported by previous researches (Buckle et al., 2019; Matsumoto et al., 2012). ACACA gene polymorphism with milk fatty acid had an opportunity as a marker-assisted selection. GG genotype can be selected to increase SFA quality, especially lauric acid, and GT genotype can be selected to increase MUFA quality, especially dodecanoic acid. However, this condition needs to be evaluated further and the effect of the SNP of the ACACA gene on milk fatty acid. The utilization of the ACACA gene g.2203G>T SNP in the future as molecular marker that the GG genotype for lauric fatty acid and GT genotype has an opportunity for dodecanoic acid.

Triglyceride milk fat is synthesized by more than 400 different fatty acids, which makes milk fat the most complex of all-natural fat. Almost all of these fatty acids are in small amounts and only about 15 types of fatty acids at the level of $1 \%$ or higher. Many factors are related to the variations in the amount and composition of dairy milk fatty acids. Variations in fatty acid composition could be influenced by genetic and feed factor, related to energy intake, dietary fat, dietary fiber content, and seasonal influence (Kesek et al., 2017; Ropka-Molik et al., 2017). The other factors that affect the fatty acids composition of the produced milk are individual variation based on clump, species, and feed (Matsumoto et al., 2012). At present, there have been many studies relating to the genetic effect on potential economic characteristics through major gene exploration. The effect of ACACA polymorphism had been analyzed on meat fat composition in different cattle populations (Kesek et al., 2017; Matsumoto et al., 2012). SNPs in several genes that play a role in fat synthesis or metabolic pathways have been linked to the percentage of milk fat or milk fat production. Based on Table 2, differences in genotype from the ACACA gene had been shown to be influenced by SFA and UFA.

\section{CONCLUSION}

The ACACA gene g.2203G>T SNP of the local HF cattle expressed the two genotypes of GG and GT with GG genotype dominant to GT genotype leading to high $\mathrm{G}$ allele and low T allele. The ACACA gene g.2203G>T SNP has potential genetic markers to increase milk fatty acids, GT genotype to increase dodecanoic acid (PUFA) and reduce the GG genotype especially for lauric acid (SFA).

\section{CONFLICT OF INTEREST}

Jakaria and Asep Gunawan serve as editor of the Tropical Animal Science Journal, but have no role in the decision to publish this article. The authors also certify that there is no conflict of interest with any financial organization regarding the material discussed in the manuscript.

\section{ACKNOWLEDGEMENT}

This work was supported by the Ministry of Agriculture of the Republic of Indonesia for its contribution to support funding for this research through the National Agricultural Research and Development Partnership Program (KKP3N). The authors thank the staff of Indonesian Research Institute for Animal Production (IRIAP), Animal Breeding Center and Forage Feed of Baturraden (ABCFFB), Central Java Province, Animal Husbandry Training Center of Cikole (AHTCC), West Java Province, Singosari Artificial Insemination Station (Singosari AIS), East Java Province, and Lembang Artificial Insemination (Lembang AIS), West Java Province contributions for collecting data in this study.

\section{REFERENCES}

Abbas, C.A., \& A.A. Sibirny 2011. Genetic control of biosynthesis and transport of riboflavin and flavin nucleotides and construction of robust biotechnological producers. Microbiol. Mol. Biol. Rev. 75:321-360. https://doi. org/10.1128/MMBR.00030-10

Abu-Elheiga, L., A. Jayakumar, A. Baldini, S.S. Chirala, \& S.J. Wakil. 1995. Human acetyl-CoA carboxylase: characterization, molecular cloning, and evidence for two isoforms. PNAS 92:4011-4015. https://doi.org/10.1073/pnas.92.9.4011

Abu-Elheiga, L., H. Wu, Z. Gu, R. Bressler, \& S.J. Wakil. 2012. Acetyl-CoA carboxylase 2-/- mutant mice are protected against fatty liver under high-fat, high-carbohydrate dietary and de novo lipogenic conditions. J. Biol. Chem. 287:12578-12588. https://doi.org/10.1074/jbc.M111.309559

Bora, D., G. Venkatesan, V. Bhanuprakash, V. Balamurugan, M. Prabhu, M.S. Sankar, \& R. Yogisharadhya. 2011. TaqMan real-time PCR assay based on DNA polymerase gene for rapid detection of Orf infection. Journal of virological methods. 178:249-252. https://doi.org/10.1016/j. jviromet.2011.09.005

Braglia, S., M. Zappaterra, P. Zambonelli, M. Comella, S. Dall'Olio, \& R. Davoli. 2014. Analysis of g. 265T> C SNP of fatty acid synthase gene and expression study in skeletal muscle and backfat tissues of Italian Large White and Italian Duroc pigs. Liv. Sci. 162:15-22. https://doi. org/10.1016/j.livsci.2014.01.014

Buckle, K.A., R. Edwards, G. Fleet, \& M. Wootton. 2019. Ilmu pangan. Translated by H. Purnomo and Adiono. $17^{\text {th }}$ ed. Universitas Indonesia Press. Jakarta.

Demeke, T., T. Gräfenhan, R.M. Clear, A. Phan, I. Ratnayaka, J. Chapados, S.K. Patrick, D. Gaba, A. Lévesque, \& K.A. Seifert. 2010. Development of a specific TaqMan ${ }^{\circledR}$ real-time PCR assay for quantification of Fusarium graminearum clade 7 and comparison of fungal biomass determined by PCR with deoxynivalenol content in wheat and barley. Intrn J. Food Micro. 141:45-50. https://doi. org/10.1016/j.ijfoodmicro.2010.04.020

Divis, P.C., S.E. Shokoples, B. Singh, \& S.K. Yanow. 2010. A TaqMan real-time PCR assay for the detection and quantitation of Plasmodium knowlesi. Malaria Journal. 9:344. https://doi.org/10.1186/1475-2875-9-344

Gacek, K., P.E. Bayer, I. Bartkowiak-Broda, L. Szala, J. 
Bocianowski, D. Edwards, \& J. Batley. 2017. Genomewide association study of genetic control of seed fatty acid biosynthesis in Brassica napus. Frontiers in Plant Science. 7:2062. https://doi.org/10.3389/fpls.2016.02062

García-Fernández, M., B. Gutiérrez-Gil, E. Garcia-Gámez, \& J.J. Arranz. 2010. Identification of single nucleotide polymorphisms in the ovine acetyl-CoA carboxylase-alpha gene. Small Rumin. Res. 90:34-40. https://doi.org/10.1016/j. smallrumres.2009.12.010

Gunawan, A., D. Anggrela, K. Listyarini, M. Abuzahra, J. Jakaria, M. Yamin, I. Inounu, \& C. Sumantri. 2018. Identification of Single Nucleotide Polymorphism and Pathway Analysis of Apolipoprotein A5 (APOA5) related to fatty acid traits in Indonesian sheep. Trop. Anim. Sci. J. 41:165-173. htps://doi.org/10.5398/tasj.2018.41.3.165

Gunawan, A., R.S. Harahap, K. Listyarini, \& C. Sumantri. 2019. Identifikasi keragaman gen DGAT1 serta asosiasinya terhadap karakteristik karkas dan sifat perlemakan domba. JIPTHP 6:259-266. http://dx.doi.org/10.33772/jitro. v6i2.7141

Hymas, W.C., A. Mills, S. Ferguson, J. Langer, R.C. She, W. Mahoney, \& D.R. Hillyard. 2010. Development of a multiplex real-time RT-PCR assay for detection of influenza A, influenza B, RSV and typing of the 2009-H1N1 influenza virus. J. Virol. Meth. 167:113-118. https://doi.org/10.1016/j. jviromet.2010.03.020

Kozera, B., \& M. Rapacz. 2013. Reference genes in real-time PCR. J. App. Gen. 54:391-406. https://doi.org/10.1007/ s13353-013-0173-x

Kęsek, M. M., G. Smołucha, \& A.E. Zielak-Steciwko. 2017. Acetyl-coA carboxylase $\alpha$ and stearoyl-coA desaturase genes polymorphism and their influence on fatty acid profile in milk of polish holstein-friesian cows. Ann. Anim. Sci. 17:993-1006. https://doi.org/10.1515/aoas-2017-0003

Lanfranco, M.F., P.K. Seitz, M.V. Morabito, R.B. Emeson, E. Sanders-Bush, \& K.A. Cunningham. 2009. An innovative real-time PCR method to measure changes in RNA editing of the serotonin $2 \mathrm{C}$ receptor (5-HT2CR) in brain. J. Neurosci. Meth. 179:247-257. https://doi.org/10.1016/j. jneumeth.2009.01.027

Livingstone, K.M., J.A. Lovegrove, \& D.I. Givens. 2012. The impact of substituting SFA in dairy products with MUFA or PUFA on CVD risk: evidence from human intervention studies. Nutr. Res. Rev. 25:193-206. https://doi.org/10.1017/ S095442241200011X

Marchitelli, C., G. Contarini, G. De Matteis, A. Crisà, L. Pariset, M.C. Scatà, G. Catillo, F. Napolitano, \& B. Moioli. 2013. Milk fatty acid variability: effect of some candidate genes involved in lipid synthesis. J. Dairy Res. 80:165-173. https://doi.org/10.1017/S002202991300006X

Matsumoto, H., K. Sasaki, T. Bessho, E. Kobayashi, T. Abe, S. Sasazaki, K. Oyama, \& H. Mannen. 2012. The SNPs in the ACACA gene are effective on fatty acid composition in Holstein milk. Mol. Biol. Reports. 39:8637-8644. https://doi. org/10.1007/s11033-012-1718-5

Micha, R., \& D. Mozaffarian. 2010. Saturated fat and cardiometabolic risk factors, coronary heart disease, stroke, and diabetes: a fresh look at the evidence. Lipids. 45:893-905. https://doi.org/10.1007/s11745-010-3393-4

Najafpanah, M.J., M. Sadeghi, A. Zali, H. MoradiShahrebabak, \& H. Mousapour. 2014. Chromium downregulates the expression of Acetyl CoA Carboxylase 1 gene in lipogenic tissues of domestic goats: a potential strategy for meat quality improvement. Gene. 543:253-258. https://doi.org/10.1016/j.gene.2014.04.006

Navarro, E., G. Serrano-Heras, M. Castaño, \& J. Solera. 2015. Real-time PCR detection chemistry. Clinica Chimica Acta. 439:231-250. https://doi.org/10.1016/j.cca.2014.10.017

Nei, M. 1987. Molecular evolutionary genetics. 512 pp. Columbia university press, New York. https://doi.org/10.7312/ nei-92038

Pilarczyk, R., J. Wójcik, P. Sablik, \& P. Czerniak. 2015. Fatty acid profile and health lipid indices in the raw milk of Simmental and Holstein-Friesian cows from an organic farm. South African J. Anim. Sci. 45:30-38. https://doi. org/10.4314/sajas.v45i1.4

Ropka-Molik, K., J. Knapik, M. Pieszka, T. Szmatoła, \& K. Piórkowska. 2017. Nutritional modification of SCD, ACACA and LPL gene expressions in different ovine tissues. Archiv Fuer Tierzucht. 60:243. https://doi.org/10.5194/ aab-60-243-2017

Salter, A. 2013. Dietary fatty acids and cardiovascular disease. Animal. 7:163-171. https://doi.org/10.1017/ S1751731111002023

Shin, S.C., J.P. Heo, \& E.R. Chung. 2011. Effect of Single Nucleotide Polymorphisms of Acetyl-CoA Carboxylase $\alpha$ (ACACA) gene on carcass traits in Hanwoo (Korean cattle). Asian-Australas. J. Anim. Sci. 24:744-751. https://doi. org/10.5713/ajas.2011.10396

Singh, R., V. Yadav, \& N. Saini. 2015. MicroRNA-195 inhibits proliferation, invasion and metastasis in breast cancer cells by targeting FASN, HMGCR, ACACA and CYP27B1. Scientific Reports. 5:17454. https://doi.org/10.1038/ srep17454

Siri-Tarino, P.W., Q. Sun, F.B. Hu, \& R.M. Krauss. 2010. Saturated fatty acids and risk of coronary heart disease: modulation by replacement nutrients. Current Atherosclerosis Reports 12:384-390.https://doi.org/10.1007/ s11883-010-0131-6

Torkildsen, Ø., S. Wergeland, S. Bakke, A.G. Beiske, K.S. Bjerve, H. Hovdal, R. Midgard, F. Lilleås, T. Pedersen, \& B. Bjørnarå. 2012. $\omega-3$ fatty acid treatment in multiple sclerosis (OFAMS Study): a randomized, double-blind, placebo-controlled trial. Archives of Neurology. 69:10441051. https://doi.org/10.1001/archneurol.2012.283

Wang, M.L., P. Khera, M.K. Pandey, H. Wang, L. Qiao, S. Feng, B. Tonnis, N.A. Barkley, D. Pinnow, \& C.C. Holbrook. 2015. Genetic mapping of QTLs controlling fatty acids provided insights into the genetic control of fatty acid synthesis pathway in peanut (Arachis hypogaea L.). PLoS One. 10. https://doi.org/10.1371/journal.pone.0119454

Wei, L., H. Miao, R. Zhao, X. Han, T. Zhang, \& H. Zhang. 2013. Identification and testing of reference genes for Sesame gene expression analysis by quantitative realtime PCR. Planta. 237:873-889. https://doi.org/10.1007/ s00425-012-1805-9

Zhang, S., T.J. Knight, J.M. Reecy, T.L. Wheeler, S. Shackelford, L.V. Cundiff, \& D.C. Beitz. 2010. Associations of polymorphisms in the promoter I of bovine acetyl-CoA carboxylase- $\alpha$ gene with beef fatty acid composition. Anim. Genet. 41:417-420. https://doi. org/10.1111/j.1365-2052.2009.02006.x 